Vol. 2, No. 1 | January - June 2019

\title{
Review on SCR catalysts by focusing impacts of sulfur on SCR performance
}

\author{
Ghazanfar Mehdi ${ }^{1}$, Song Zhou ${ }^{1}$, Yuanqing Zhu ${ }^{1}$, Zubair Ali Shah ${ }^{1}$, Kishore \\ Chand $^{2}$, Raza Waleed ${ }^{3}$, Asif Raza ${ }^{4}$, Sanaullah ${ }^{4}$
}

\begin{abstract}
:
Marine diesel engines are extensively used for transportation and as well as for power generation purpose because of its higher durability, thermal and fuel efficiency than the gasoline engines. But the marine diesel engine produced severe NOx emissions that are currently well discussed issue needed to be solved due to its serious health and environmental problems. At the same time, because of increasing stringent regulations of NOx emissions it is necessary for ships to meet the international maritime organization (IMO) Tier III regulations in NOx emission control areas (ECA). It is enforced for the vessels that are constructed on and after the 1st January 2016. Therefore, a demand for well-functioning NOx reduction technology is required. Currently SCR is the most dominant and mature technology used to reduce the NOx with ammonia over the SCR catalyst. SCR catalyst is the core part of SCR system; hence this review described the different types of catalysts and their behavior under different conditions. Furthermore, the deactivation of SCR catalyst occurs by different mechanisms; however, the most significant mechanism is sulfur poisoning. Reaction temperature and availability of ammonia is also significant parameter for sulfur poisoning. Therefore, it is necessary to investigate how sulfur behaves with SCR catalysts. Even though many studies have been performed on Sulphur poisoning of catalysts but still requires complete understanding. This review covers the sulfur poisoning of vanadium and $\mathrm{Cu}$-zeolites based SCR catalysts with mainly focus on Cu-zeolites because of its sulfur sensitivity.
\end{abstract}

Keywords: marine diesel engine, selective catalsyt reduction; vanadium;cu zeolite; sulfur

\section{Introduction}

Because of their high thermal efficiency and durability, marine diesel engines are extensively used for power generation as well as for transport purpose. However, only transportation sectors are producing almost world's $30 \%$ greenhouse gases [1]. Marine diesel engine emissions produced serious

${ }^{1}$ College of Energy and Power Engineering, Harbin Engineering University, Harbin 150001, China

${ }^{2}$ College of Material science and Chemical Engineering, Harbin Engineering University, Harbin 150001, China

${ }^{3}$ College of Underwater acoustic Engineering, Harbin Engineering University, Harbin 150001, China

${ }^{4}$ College of Mechanical and Electrical Engineering, Harbin Engineering University, Harbin 150001, China

Corresponding Author: ghazanfarmehdi22@gmail.com 
environmental hazardous gases specially $\mathrm{NO}_{\mathrm{x}}$. The carbon monoxide (CO), carbon dioxide $\left(\mathrm{CO}_{2}\right)$ and hydrocarbon $(\mathrm{HC})$ exhaust emissions is much lower in marine diesel engines, as in comparison to automobile design engines and on the contrary, it produces more detrimental Nitrogen oxides $\left(\mathrm{NO}_{\mathrm{x}}\right)$ emissions [2]. $\mathrm{NO}_{\mathrm{x}}$ emissions are produced due to the combustion process of diesel engine. There are three main sources of $\mathrm{NO}_{\mathrm{x}}$ formation named as thermal $\mathrm{NO}_{\mathrm{x}}$, fuel $\mathrm{NO}_{\mathrm{x}}$ and prompt $\mathrm{NO}_{\mathrm{x}}$. The involvement of fuel $\mathrm{NO}_{\mathrm{x}}$ and prompt $\mathrm{NO}_{\mathrm{x}}$ to the total $\mathrm{NO}_{\mathrm{x}}$ emissions is negligible [4]. Basically thermal $\mathrm{NO}_{x}$ is the major contributor of $\mathrm{NO}_{\mathrm{x}}$ formation throughout the whole combustion process [3]. $\mathrm{NO}_{\mathrm{x}}$ is very noxious, hazardous and it creates an irritation. It is responsible for the headache and nausea [5]. $\mathrm{NO}_{\mathrm{x}}$ can react with existence of sunlight and other organic compounds to form ozone layer. In the troposphere Ozone is named as ground level ozone. When $\mathrm{NO}_{\mathrm{x}}$ is reacted with water, nitric acid can be formed which is the major source of acid rain [6]. In order to reduce $\mathrm{NO}_{\mathrm{x}}$ from ships, many national governments and international organizations in the world have promulgated different regulations on shipping emissions, and also enforced strict requirements on $\mathrm{NO}_{\mathrm{x}}$ emission in the Emission Control Areas (ECA) [7]. In 2016, IMO Tier III standard on $\mathrm{NO}_{x}$ emission proposed by International Maritime Organization (IMO) has already been enforced in North America Emission Control Area (ECA), including the East and West coast of the USA and Caribbean [8]. Due to the increasing stringent emission regulations, it is necessary for vessels to meet the IMO Tier III legislations applied for ships constructed on and after the 1st January 2016 in NOx emission control areas. Fig. 1 represents the limits of $\mathrm{NO}_{\mathrm{x}}$ legislations. It is enforced that, during the operation of ships $\mathrm{NO}_{\mathrm{x}}$ emissions should not exceed $3.4 \mathrm{~g} / \mathrm{kWh}$. In the requirement of Tier III $\mathrm{NO}_{\mathrm{x}}$ emission decreased up to $75 \%$ as compared to IMO Tier II [9].

Currently three most mature technologies such as exhaust gas recirculation (EGR),
Selective catalyst reduction (SCR) and dual fuel are mostly used worldwide to control the $\mathrm{NO}_{\mathrm{x}}$ as shown in Fig. 2 [10]. It has been observed that in order to decrease the $\mathrm{NO}_{\mathrm{x}}$ emission intensely and meet the requirements of IMO Tier III, SCR, EGR and Dual fuel can be the effect methods. SCR and EGR are the most feasible and mature techniques used to decrease the $\mathrm{NO}_{\mathrm{x}}$ of two stroke marine diesel engines. But the dual fuel is not good

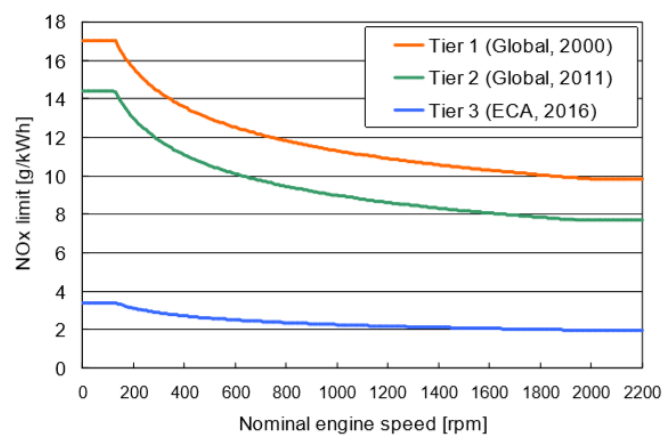

Fig. 1. Represents the limits of $\mathrm{NO}_{\mathrm{x}}$ legislations [9]

option, because the low speed two stroke marine diesel engines are still using HFO (Heavy Fuel Oil). But SCR in comparison to EGR is the front runner technology in marine diesel engine due to its higher $\mathrm{DeNO}_{\mathrm{x}}$ efficiency [11]. In EGR system $\mathrm{NO}_{x}$ can be reduced by diverting the exhaust flow of burned gases into combustion chamber. As the recirculated burned gas entered, it is responsible for lowering the adiabatic flame temperature.

Due to the lowering of in-cylinder temperature $\mathrm{NO}_{\mathrm{x}}$ formation has been reduced. But as a result of temperature reduction, the efficiency of engine also decreased which tends to increase the fuel consumption. Therefore, SCR is the most 


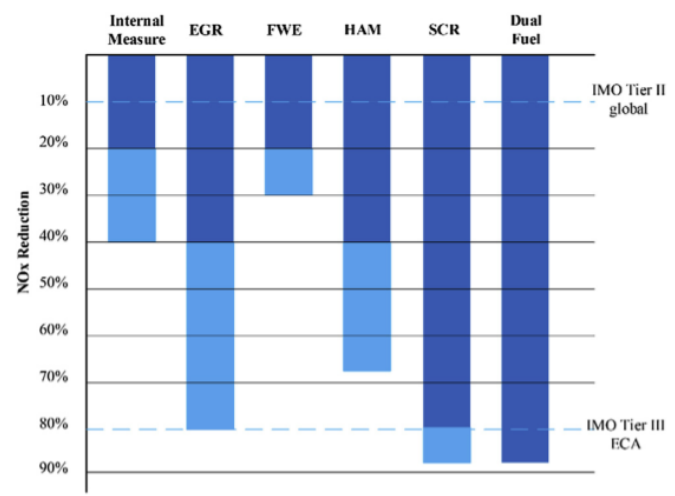

Fig. 2. $\mathrm{NO}_{\mathrm{x}}$ Removal Technologies prominent and leading technology because it operates with higher efficiency without compromising on both flame temperature and $\mathrm{NO}_{\mathrm{x}}$ conversion [12].

SCR is the dominant technology used to meet the most recent emission standards due to its technical maturity, better fuel economy and low cost for the emission reduction. SCR is means of converting $\mathrm{NO}_{x}$ into $\mathrm{N}_{2}$ and $\mathrm{H}_{2} \mathrm{O}$ by using catalyst and oxygen $\left(\mathrm{O}_{2}\right)$ [13]. However, pressure drop occurs at SCR catalyst therefore more efficient turbocharger is necessary for SCR system.

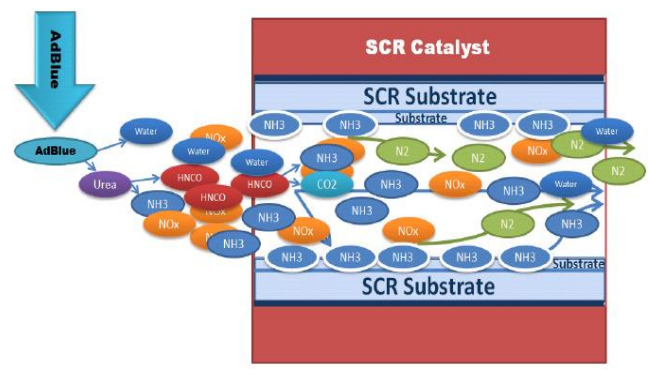

Fig. 3. Systematic representation of SCR System

As the $\mathrm{NO}_{\mathrm{x}}$ is decreased into $\mathrm{N}_{2}$, between the temperature ranges of $300-400{ }^{\circ} \mathrm{C}$, the load of engine must be $40 \%$ and above. Ammonia $\left(\mathrm{NH}_{3}\right)$ will start burning when the exhaust temperature of engine goes beyond the 400 ${ }^{\circ} \mathrm{C}$ which will make the system ineffective. SCR catalyst reaction will become slow and undesirable reactions such as formation of ammonium sulfates will occur when the temperature goes below $270{ }^{\circ} \mathrm{C}$, which ultimately destroy the catalyst. Therefore, SCR reaction is mainly restricted by the catalyst activity, species concentration and reaction temperature [14]. Fig. 3 shows the systematic representation of SCR system.

\section{Challenges related to SCR system}

The major challenges involved with SCR systems is the reduction of catalytic converter volume at low temperatures and the suitable dosing strategy for $\mathrm{NH}_{3}$ at frequently varying load conditions of the diesel engines. Additionally, the risk associated concerning storing and handling of gaseous $\mathrm{NH}_{3}$ is significant and consequentially it is not commonly used as a reducing agent directly. For reasons of toxic nature of $\mathrm{NH}_{3}$, handling and storing problems, urea is the preferred substitute for $\mathrm{NH}_{3}$ as a reducing agent in automotive applications. The best procedure is injecting Urea Water Solution (UWS) in the form of spray to hot exhaust stream before the entry to the SCR catalyst [15]. Urea is an environmentally benign chemical which makes it more suitable for application of the SCR process. Urea is a fertilizer used in agriculture and available in a number of quality grades at a lower cost. Development of Urea-SCR over $\mathrm{NH}_{3}-\mathrm{SCR}$ has gained momentum due to various problems involved with the use of $\mathrm{NH}_{3} . \mathrm{NH}_{3}$ is corrosive, toxic in nature and also a secondary pollutant. In order to introduce $\mathrm{NH}_{3}$ into the exhaust gas stream, proper dosage control mechanism is required [16].

The main advantage with this SCR system is high De-NOx efficiency $(90 \%$ or higher). The disadvantages involve the space required for the catalyst, high capital and operating costs, formation of other emissions $\left(\mathrm{NH}_{3}\right.$ slip) and formation of undesirable species which may lead to catalyst poisoning and deactivation. The $\mathrm{NH}_{3}$ slip can be controlled by installing an oxidation catalyst after the SCR system. Although the SCR system has some drawbacks, the technology has been chosen by the majority of the diesel engine manufactures due to absence of better technology to meet the stringent emission standards [15]. 
There are two main objectives related to SCR system.

- To minimize the $\mathrm{NO}_{\mathrm{x}}$ emissions

- $\quad$ To minimize the ammonia slip

Following factors should be controlled to get the maximum output in above two objectives.

- Design optimization

- Control system

- Temperature fluctuations

- Low operating temperature

- Poisonous species present in the catalyst

- Mechanical vibrations

- Flow variations

Throughout the low load operating conditions, exhaust temperature is also low; this will put direct effect on the chemical reaction of SCR catalyst, which makes reaction slow at low temperature for characteristic composition of exhaust gas. Variations of engine load influenced the flow rate of exhaust gas, temperature, and composition of exhaust gases. Therefore, it is necessary to control the above factors to improve the $\mathrm{NO}_{\mathrm{x}}$ conversion and to reduce the ammonia slip. In general, there is trade off relationship in between $\mathrm{NO}_{\mathrm{x}}$ reduction and ammonia slip [17].

\section{Research evolution of SCR catalyst}

Catalyst is the core part of SCR system. It has been used for reducing the activation energy, $\mathrm{NO}_{\mathrm{x}}$ decomposition temperature during reaction, to avoid the incidence of unwanted reactions, increase the amount of $\mathrm{N}_{2}$ in production side and by this means reaction efficiency has been improved. Catalysts selection is the most important. Particularly, the competent SCR catalysts possessed the characteristics as listed below:

- $\operatorname{DeNO}_{x}$ ability should be high

- Anti-poisoning capacity should be high

- Strong mechanical strength

- Operating temperature should be proper.

\subsection{Vanadium based SCR catalysts (VSCR)}

A VSCR catalyst is the established technology, mostly used in mobile applications [18]. It is the cheapest of all SCR catalysts [19] and also well known for sulfur tolerance [20]. VCRs operates approximately in the temperature range of $280-500{ }^{\circ} \mathrm{C}[19,21,22]$. It is also used at low temperatures, but as a result low $\mathrm{NO}_{\mathrm{x}}$ removal efficiency occurs. A VSCR catalyst is mainly composed with the mixture of $\mathrm{WO}_{3} / \mathrm{V}_{2} \mathrm{O}_{5} / \mathrm{TiO}_{2}$, where, $\mathrm{WO}_{3}$ is the thermal promoter and used to increase the catalyst acidity, $\mathrm{V}_{2} \mathrm{O}_{5}$ is worked as an active component and $\mathrm{TiO}_{2}$ is added as a carrier material [20].

The main disadvantage of VSCR is the sudden decline in the performance of acidity and selectivity at the higher temperatures. Deterioration of catalyst or alkali poisoning starts when the temperature window in between of $550-600{ }^{\circ} \mathrm{C}$ [18]. Toxicity of vanadium species is also an important issue [19].

\subsection{Cu-zeolites based SCR}

During the last few years, Cu-zeolites based SCR catalysts becomes the most preferred catalyst because of its high performance [19]. It is commonly used in movable applications [23]. The key benefits related to $\mathrm{Cu}$-zeolites based SCR catalysts are the hydrothermal stability and higher $\mathrm{NO}_{\mathrm{x}}$ activity within the temperature window of 150 to $600{ }^{\circ} \mathrm{C}$ [24]. Cu-zeolites based SCR catalysts have good performance even at low temperatures and it is also less sensitive on activity because of the $\mathrm{NO}_{2}$ Concentration variations [19]. However, $\mathrm{Cu}$ zeolites are recognized for their higher sensitivity towards sulfur than the vanadium-based catalysts [25]. A MFI framework of Cu/ZSM-5 was first discovered in 1986, as an effective catalyst used for SCR system [26]. Currently, keen interest is showed towards catalyst structure based on the small pores; with special focus on the Cu/SAPO-34 and on $\mathrm{Cu} / \mathrm{SSZ}-13$. Both catalysts have chabazite type structure but the composition of elements is different. While Cu/SAPO-34 
is silicoaluminoposphates and $\mathrm{Cu} / \mathrm{SSZ}-13$ are zeolites [27]. While comparing the small pore structure of zeolites catalyst with the structure of larger pore, the structure with small pores has been observed more hydrothermally stable. Besides a very high $\mathrm{NO}_{\mathrm{x}}$ activity and selectivity can be achieved. Furthermore, less amount of by products such as $\mathrm{N}_{2} \mathrm{O}$ can be formed during operating temperature range [27] and also it is less vulnerable for hydrocarbon poisoning [19].
While the comparing of $\mathrm{Cu} / \mathrm{SAPO}-34$ and $\mathrm{Cu} / \mathrm{SSZ}-13$, it was observed that $\mathrm{Cu} / \mathrm{SAPO}-$ 34 has been more hydrothermal stable rather than $\mathrm{Cu} / \mathrm{SSZ}-13$ [26].

A number of catalysts proved to be suitable in favor of SCR reactions. The most important proper components are transit oxides of metal, although $\mathrm{Al}_{2} \mathrm{O}_{3}$, zeolite, $\mathrm{TiO}_{2}, \mathrm{SiO}_{2}$ and carbon are frequently used

Table I. Summarized description of main SCR catalysts

\begin{tabular}{|c|c|c|c|c|c|}
\hline $\begin{array}{l}\text { Type of } \\
\text { catalysts }\end{array}$ & $\begin{array}{c}\text { Proper } \\
\text { components }\end{array}$ & Carrier & Advantages & Disadvantages & Ref: \\
\hline $\begin{array}{l}\text { Commercial } \\
\text { catalyst based } \\
\text { on vanadium } \\
\text { titanium }\end{array}$ & $\mathrm{V}_{2} \mathrm{O}_{5}$ & $\mathrm{TiO}_{2}$ & $\begin{array}{l}\mathrm{SO}_{2} \text { resistance is high, } \\
\mathrm{SCR} \text { activity at high } \\
\text { and low temperature }\end{array}$ & Oxidation of $\mathrm{SO}_{2}$ & [28-30] \\
\hline Noble metals & $\mathrm{Sn}, \mathrm{Ag}$, etc. & $\begin{array}{l}\mathrm{TiO}_{2} \\
\mathrm{Al}_{2} \mathrm{O}_{3} \\
\text { etc. }\end{array}$ & $\begin{array}{c}\mathrm{H}_{2} \mathrm{O} \text { and } \mathrm{SO}_{2} \text { resistance } \\
\text { is high; high low } \\
\text { temperature } \mathrm{SCR} \\
\text { activity }\end{array}$ & $\begin{array}{c}\text { Narrow } \\
\text { temperature } \\
\text { window; high } \\
\text { cost; generation } \\
\text { of } \mathrm{NO}_{2} \text {; ammonia } \\
\text { oxidation }\end{array}$ & {$[31,32]$} \\
\hline $\begin{array}{c}\text { Oxides of } \\
\text { metal }\end{array}$ & $\begin{array}{c}\mathrm{V}_{2} \mathrm{O}_{5}, \mathrm{Cuo}, \\
\mathrm{CeO}_{2}, \\
\mathrm{MNO}_{\mathrm{x}}, \\
\mathrm{CoO}_{\mathrm{x}}, \mathrm{FeO}, \\
\text { and other } \\
\text { composite } \\
\text { oxide. }\end{array}$ & $\begin{array}{c}\mathrm{TiO}_{2} \\
\mathrm{Al}_{2} \mathrm{O}_{3} \text { etc. }\end{array}$ & $\begin{array}{l}\text { SCR activity is high at } \\
300-400 \mathrm{C} \text {; thermal } \\
\text { stability is good; } \\
\text { poisoning resistance is } \\
\text { high }\end{array}$ & $\begin{array}{c}\text { Poor activity at } \\
\text { low temperatures }\end{array}$ & {$[33,34]$} \\
\hline Zeolite & $\begin{array}{l}\mathrm{Mn}, \mathrm{Ce}, \mathrm{Fe}, \\
\mathrm{Co}, \mathrm{Cu}, \mathrm{Cr}, \\
\text { etc. }\end{array}$ & Zeolite & $\begin{array}{l}\text { Wide temperature } \\
\text { window }\end{array}$ & $\begin{array}{l}\text { Hydrothermal } \\
\text { stability is poor }\end{array}$ & {$[35,36]$} \\
\hline $\begin{array}{l}\text { Carbon } \\
\text { catalyst }\end{array}$ & $\begin{array}{l}\mathrm{V}_{2} \mathrm{O}_{5}, \mathrm{CeO}_{2} \\
\mathrm{MNO}_{\mathrm{x}}, \text { etc. }\end{array}$ & $\begin{array}{l}\text { Active } \\
\text { carbon, } \\
\text { Active } \\
\text { carbon } \\
\text { filter, } \\
\text { carbon } \\
\text { nanotubes }\end{array}$ & $\begin{array}{l}\text { Easy regeneration, } \\
\text { Specific surface area is } \\
\text { large, chemical stability } \\
\text { is high, high low } \\
\text { temperature activity }\end{array}$ & $\begin{array}{l}\text { Poor } \mathrm{SO}_{2} \\
\text { resistance; energy } \\
\text { consumption is } \\
\text { high; frequent } \\
\text { regeneration. }\end{array}$ & {$[37,38]$} \\
\hline
\end{tabular}

like carriers. All catalysts have possessed different advantages and disadvantages and $\mathrm{DeNO}_{\mathrm{x}}$ properties, which have been described in table. 2 .

\subsection{Catalayst Deactivation}

The selectivity and activity loss of catalyst over time is known as catalyst deactivation. Mostly there are three mechanisms for the deactivation of SCR catalysts named as thermal, chemical and mechanical. These mechanisms of catalyst decay can be further elaborated into six submechanisms where thermal decay by thermal deprivation such as fouling, sintering and poisoning. Chemical decay can happen due to 
vapor formation, solid-solid reactions and poisoning. Mechanical decay can occur through crushing or fouling. The most important mechanisms for catalyst deactivation are poisoning and fouling [39].

When poisoning is strong, gas-surface chemisorptions happen on catalyst surface; hence, as a result, it blocks the sites for catalyst reaction. Poisoning of species depends upon the adsorption strength of species. The poisoning of species is either produced due to the change in the electronic

\section{Sulfur poisoning of SCR catalsyts}

Deactivation of SCR catalyst occurs by different mechanisms; however, the most significant mechanism is sulfur poisoning. The important factor that influences the sulfur poisoning is the type of catalyst material. Some are more and some are less sulphur tolerant depending on the catalyst materials. Reaction temperature and availability of ammonia is also significant parameter for sulfur poisoning. Therefore, it is necessary to investigate how sulfur behaves with SCR catalysts. Although many studies have been done on sulfur poisoning of catalysts, still it requires complete understanding. This review covers the sulfur poisoning of vanadium-based catalyst and $\mathrm{Cu}$-zeolites SCR catalysts with mainly focus on $\mathrm{Cu}$-zeolites because of its sulfur sensitivity.

Many studies present in this review are to investigate the impact of sulfur on SCR activity by accelerating the lab aging in flow reactors. The accelerated aging in lab has been carried out by using the different catalysts for sulfur under different conditions. There are different sulfation methods named as $\mathrm{SO}_{2}$ exposure in the presence of ammonia, $\mathrm{SO}_{2}$ exposure under different SCR conditions or $\mathrm{SO}_{3}$ exposure at different temperature ranges. Few studies also related to the investigation of sulfur poisoning through experimental setup by using fuel with high sulfur contents. The experimental setup which is mostly used to investigate the sulfur or geometrical structure of surface or it just blocks the adsorption sites physically. The poisoning of species can be slow or fast, it mostly depending upon the concentration of poison. It can be irreversible or reversible depends upon the adsorption strength of poison [39]. Fouling is due to deposition of species physically produced from fluid phase over the catalyst pores and in the catalytic surface. This is responsible for the blockage of pores and sites, which ultimately result in the loss of activity of catalyst [39].

\subsection{Sulfur in exhaust gases}

The main source of sulfur at the diesel exhaust is originated from the engine lubricating oil and the presence of sulfur contents in the fuel [40]. Throughout the last few years, contents of sulfur present in diesel fuel decreased extensively. Hence, as a result, $\mathrm{SO}_{2}$ level reduced in the atmosphere and also to avoid the use of highly efficient aftertreatment system at the diesel exhaust which is more sulfur sensitive. Today, In North America and Europe Ultra-low sulfur diesel (ULSD) fuel is used which contains sulfur contents less than 10-15 ppm [41]. At diesel exhaust, sulfur oxides $\left(\mathrm{SO}_{\mathrm{x}}\right)$ concentration depends upon the air fuel ratio and contents of sulfur present in the diesel fuel, this relation is represented in Fig 4 [42]. Sulfur is mostly in the form of $\mathrm{SO}_{2}$ at the exhaust of diesel engine. It can be further oxidized into $\mathrm{SO}_{3}$ when the SCR system is located beyond the diesel oxidation catalyst (DOC) [40].

\subsection{SCR operated on Heavy Fuel Oil (HFO)}

Heavy fuel oil (HFO) is well known for its challenges and disadvantages related to SCR system because it contains high sulfur contents in the diesel fuel. Therefore, it allows the oxidation of $\mathrm{SO}_{2}$ to $\mathrm{SO}_{3}$ during the $\mathrm{SCR}$ reaction. It is responsible for the formation of white plumes and Ammonium Bi sulfate (ABS). Furthermore, with the use of HFO the natural contents of vanadiumbased catalysts result in the prominent oxidation of $\mathrm{SO}_{2}$. Therefore, at present it is 
necessary to design the SCR system in a way that resists the unwanted side reactions.

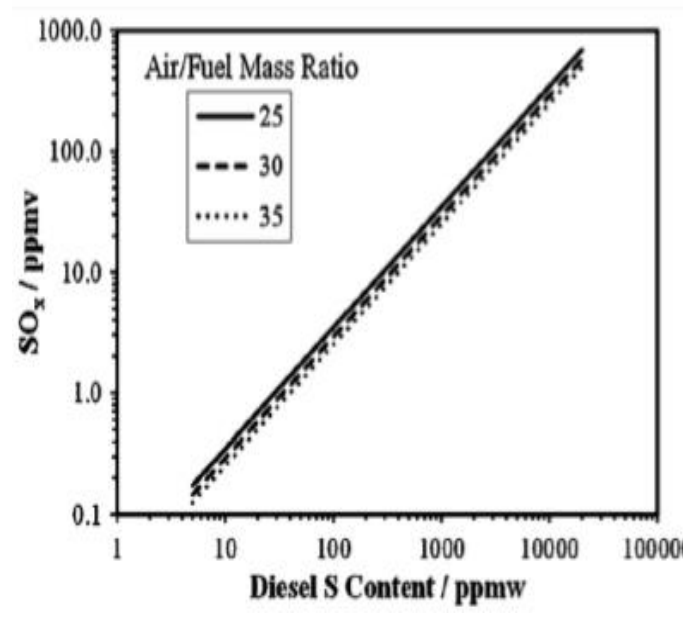

Fig. 4. Relation in between the contents of sulfur in the diesel fuel and $\mathrm{SO}_{\mathrm{x}}$ concentration at diesel exhaust for three air to fuel ratio

In two-stroke diesel engines, because of the high energy efficiency, the temperature of gases at the diesel exhaust is low after the turbocharger. It is in between of the 230- 260 ${ }^{\circ} \mathrm{C}$ depending upon the load of the diesel engine. Low temperature at diesel exhaust creates problem for the SCR system when the $\mathrm{HFO}$ is used in the diesel engine. Hence, in order to get the high fuel flexibility, the main precedence of diesel engine is to produce the exhaust gases with suitable temperature window, which ultimately results in improving the SCR system. The exhaust gas temperature around 330 to $350^{\circ} \mathrm{C}$ should be ideal during the working of engine on HFO [43].

\subsection{Formation of ammonium sulfates}

Ammonium sulfates are produced when the exhaust temperature is low during the SCR catalyst reaction in the presence of $\mathrm{NH}_{3}$ and $\mathrm{SO}_{\mathrm{x}}$ as shown in reactions below:

$$
\begin{aligned}
& \mathrm{NH}_{3}+\mathrm{SO}_{3}+\mathrm{H}_{2} \mathrm{O} \rightarrow \mathrm{NH}_{4} \mathrm{HSO}_{4} \\
& 2 \mathrm{NH}_{3}+\mathrm{SO}_{3}+\mathrm{H}_{2} \mathrm{O} \rightarrow\left(\mathrm{NH}_{4}\right)_{2} \mathrm{SO}_{4} \\
& \mathrm{H}_{2} \mathrm{SO}_{4}+\mathrm{NH}_{3} \rightarrow \mathrm{NH}_{4} \mathrm{HSO}_{4} \\
& \mathrm{SO}_{3}+\mathrm{H}_{2} \mathrm{O} \rightarrow \mathrm{H}_{2} \mathrm{SO}_{4}
\end{aligned}
$$

Ammonium bisulfate (ABS), $\mathrm{NH}_{4} \mathrm{HSO}_{4}$ and Ammonium sulfate $\left(\mathrm{NH}_{4}\right)_{2} \mathrm{SO}_{4}$ are responsible for the physical blockage of pores and channels of catalyst. Therefore, the result in the deactivation of catalyst. $\mathrm{ABS}$ is the most hazardous of all the species [44]. ABS is generally formed, when the temperature is in between $190-240{ }^{\circ} \mathrm{C}$ and it starts to decompose when temperature goes around $350 \quad{ }^{\circ} \mathrm{C}$ [45]. The $\left(\mathrm{NH}_{4}\right)_{2} \mathrm{SO}_{4}$ decomposition occurs in two stages, first it decomposed into $\mathrm{NH}_{3}$ and $\mathrm{NH}_{4} \mathrm{HSO}_{4}$ at about temperature of $300{ }^{\circ} \mathrm{C}$ as represented in reaction 5. Second, $\mathrm{NH}_{4} \mathrm{HSO}_{4}$ will start decomposing when the temperature reaches at higher level as shown in reaction 6 [46].

$\left(\mathrm{NH}_{4}\right)_{2} \mathrm{SO}_{4}(\mathrm{~s}) \leftrightarrow \mathrm{NH}_{4} \mathrm{HSO}_{4}(\mathrm{~s})+\mathrm{NH}_{3}(\mathrm{~g})(5)$ $\mathrm{NH}_{4} \mathrm{HSO}_{4}(\mathrm{~s}) \leftrightarrow \mathrm{NH}_{3}(\mathrm{~g})+\mathrm{SO}_{2}(\mathrm{~g})+1 / 2 \mathrm{O}_{2}$ $(\mathrm{g})+\mathrm{H}_{2} \mathrm{O}(\mathrm{g})$

\subsection{Impacts of Sulfur on vanadium based SCR catalyst}

Many authors have proved that, vanadiumbased catalysts are operated at relatively narrow temperature range $\left(300-400{ }^{\circ} \mathrm{C}\right)$ of SCR system [47, 48]. If the operating temperature goes below to the $320{ }^{\circ} \mathrm{C}$, the sulfur poisoning, specially poisoning of $\mathrm{SO}_{2}$ becomes more imperative and the selectivity and activity of the SCR catalysts decreases, significantly. Furthermore, when the temperature goes above to the $400{ }^{\circ} \mathrm{C}$, undesirable side reactions can occur which are responsible to produce $\mathrm{N}_{2} \mathrm{O}$ and $\mathrm{NO}$ from the oxidation of $\mathrm{NH}_{3}$ [49]. $\mathrm{NO}_{x}$ removal efficiency is decreased progressively by means of catalyst aging. Presence of $\mathrm{SO}_{2}$ can cause the deactivation of SCR catalysts during the SCR operation. Inhibition of $\mathrm{SO}_{2}$ is the most common problem during the activity of catalyst [47, 50, 51]. Following poisoning mechanism of $\mathrm{SO}_{2}$ is imagined when $\mathrm{NH}_{3}$-SCR process is used. On the catalyst surface, $\mathrm{SO}_{2}$ can be oxidized into $\mathrm{SO}_{3}$. The produced $\mathrm{SO}_{3}$ reacts with $\mathrm{NH}_{3}$ to generate the unwanted reactions such as $\left(\mathrm{NH}_{4}\right)_{2} \mathrm{SO}_{4}$ and $\mathrm{NH}_{4} \mathrm{HSO}_{4}$. These two generated undesirable substances deposit in the pores of SCR catalyst, which deactivate 
and block the active sites and cause the rapid decrease in the catalyst surface area [52].

The conversion rate of $\mathrm{SO}_{2}$ is vary from $1 \%$ $2 \%$ during the normal operating conditions of SCR system [53]. Many studies have proved that, in vanadium-based catalyst $\mathrm{V}=\mathrm{O}$ bond shows the important role in the oxidation of $\mathrm{SO}_{2}$ [54]. Thus, the content of $\mathrm{V}_{2} \mathrm{O}_{5}$ is generally set to be smaller in the SCR catalyst in order to avoid the generation of $\mathrm{SO}_{3}$. Water vapors appear in the flue gases and can be condensed on the surface of catalyst. It not only produces the exacerbate poisoning by the alkali metals like $\mathrm{Na}$ and $\mathrm{K}$, but also responsible for the vaporization and swelling with the increase of temperature. It damages the structure of catalyst, hence in result SCR catalyst is cracked.

It has been reported that for the physical adsorption water vapor is to compete with $\mathrm{NH}_{3}$ and $\mathrm{NO}$ on the surface of catalyst, by this means deNO $\mathrm{x}_{\mathrm{x}}$ activity of catalyst decreased [55].

The alkali metals such as $(\mathrm{Na}, \mathrm{K})$ available in fly ash also disgrace the performance of catalyst when they deposited in the catalysts. Therefore, lengthy acquisition can block pores, which results the poisoning of catalyst [51].

\subsection{Impact of sulfur on Cu-zeolite SCR catalyst}

$\mathrm{Cu}$-zeolites are the more sulfur sensitive than vanadium-based catalysts. In this review catalysts with small pores such as $\mathrm{Cu} / \mathrm{SSZ}-13$ and $\mathrm{Cu} / \mathrm{SAPO}-34$ belong to chabazite family are concerned. The exposure of $\mathrm{SO}_{2}, \mathrm{SO}_{3}$ and/or $\mathrm{SO}_{2}+\mathrm{NH}_{3}, \mathrm{SO}_{2}$ are investigated at different conditions of sulfur poisoning, also by considering the impact of temperature simultaneously.

\subsubsection{Impact of sulfur on SCR chemical reactions}

The different SCR reactions have different impact on the sulfur poisoning of $\mathrm{Cu}$-zeolites catalysts. Standard SCR reaction is much affected than the fast SCR reaction [56, 57]. Furthermore, at low temperatures catalyst activity is severely impacted than the catalyst activity at high temperatures [58].

\subsection{2. $\mathrm{SO}_{2}$ impact on $\mathrm{SCR}$ catalyst activity}

Many studies have shown the deactivation of $\mathrm{Cu}$-zeolites catalyst under the $\mathrm{SO}_{2}$ exposure and absence of $\mathrm{NH}_{3}$. It was reported that at different temperatures, the poisoning of catalyst is different. The $\mathrm{SO}_{2}$ exposure of unspecified $\mathrm{Cu}$-zeolite has been reported high deactivation of catalyst at 200 ${ }^{\circ} \mathrm{C}$ as compared with $300{ }^{\circ} \mathrm{C}$. Overall least deactivation has been found at $400{ }^{\circ} \mathrm{C}$ after the exposure of $\mathrm{SO}_{2}$ [58]. $\mathrm{Cu} / \mathrm{SSZ}-13$ also showed the same trend as above [22], catalyst was more deactivated at $250{ }^{\circ} \mathrm{C}$ as compared to $400{ }^{\circ} \mathrm{C}$ after poisoning. But the $\mathrm{Cu} / \mathrm{SAPO}-$ 34 showed the opposite trend than the $\mathrm{Cu} / \mathrm{SSZ}-13$, it has been reported that $\mathrm{Cu} / \mathrm{SAPO}-34$ was more deactivated at $250{ }^{\circ} \mathrm{C}$ than the $150{ }^{\circ} \mathrm{C}$ after sulfation [59]. Also it has been shown that the $\mathrm{Cu} / \mathrm{SAPO}-34$ was more deactivated at $400{ }^{\circ} \mathrm{C}$ as compared to $200{ }^{\circ} \mathrm{C}$ after the $\mathrm{SO}_{2}$ exposure [57].

\subsection{3. $\mathrm{SO}_{2}+\mathrm{NH}_{3}$ impact on $\mathrm{SCR}$ catalyst activity}

A comparative study between sulfation and with or without the presence of ammonia reported that, with the presence of $\mathrm{NH}_{3}$ at the temperature of $300{ }^{\circ} \mathrm{C}$ after sulfation, more deactivation of catalyst was found [56]. Also, the same trend has been shown in another study [57], at temperature $400{ }^{\circ} \mathrm{C}$ during the presence of $\mathrm{NH}_{3}$, poisoning of $\mathrm{SO}_{x}$ produced the more negative affect as compared to the poisoning of $\mathrm{SO}_{\mathrm{x}}$ without the use of $\mathrm{NH}_{3}$.

\subsection{4. $\mathrm{SO}_{2}$ and/or $\mathrm{SO}_{3}$ impact on $\mathrm{SCR}$ catalyst activity}

$\mathrm{SO}_{3}$ poisoning has produced more significant impact of deactivation as compared with $\mathrm{SO}_{2}$ poisoning. Unspecified $\mathrm{Cu}$-zeolites was used to investigate the impact of poisoning temperature. With the increase of poisoning temperature $(200,300$, $400{ }^{\circ} \mathrm{C}$ ) more deactivation has been reported [60]. Also, at the same temperature conditions, the impact of $\mathrm{SO}_{2}$ as compared with $\mathrm{SO}_{3}$ was investigated. It has been reported that poisoning of $\mathrm{SO}_{3}$ resulted more significant deactivation than the $\mathrm{SO}_{2}$ poisoning for all temperature ranges. 
During the investigation of $\mathrm{Cu} / \mathrm{SAPO}-34$ catalyst it has been observed that for $\mathrm{SO}_{3}$ poisoning temperature was an important parameter [61]. Poisoning of $\mathrm{SO}_{2}$ and $\mathrm{SO}_{2}+$ $\mathrm{SO}_{3}$ at temperature of $200{ }^{\circ} \mathrm{C}$ both has same impact on the catalyst activity. However, $\mathrm{SO}_{2}$ $+\mathrm{SO}_{3}$ poisoning at temperature of $400{ }^{\circ} \mathrm{C}$ was responsible for the severe deactivation of catalyst than the $\mathrm{SO}_{2}$ poisoning. It has been reported that the mechanism for the poisoning of $\mathrm{SO}_{2}$ and $\mathrm{SO}_{3}$ was different, whereas poisoning of $\mathrm{SO}_{2}$ is due to the adsorption and poisoning of $\mathrm{SO}_{3}$ is because of chemical reactions having activated temperature with catalyst surface.

$\mathrm{Cu}$-zeolite catalyst associated with poisoning of sulfur was studied by putting 35 ppm of $\mathrm{SO}_{2}$ in a "diesel system simulator" (DSS). It consists of diesel oxidation catalyst (DOC) at the upstream of catalyst soot filter (CSF) and followed by SCR system. Since the SCR reactor was located after the DOC, therefore some part of $\mathrm{SO}_{2}$ oxidized into $\mathrm{SO}_{3}$. It has been proved that after the 400 hours the activity of SCR reactor started to lose, which was about $4 \mathrm{~g}$ of sulfur/litre [62].

\subsubsection{Sulfur storage on $\mathrm{Cu}$-zeolites}

Many papers have been reported the storage of sulfur on $\mathrm{Cu}$-zeolite and the poisoning of $\mathrm{SO}_{2}$. It has been observed that different temperatures have different impact on sulfur storage. A Cu/SAPO-34 [59] and unspecified $\mathrm{Cu}$-chabazite [57] catalysts with chabazite structure were studied by considering the sulfur storage on catalysts. It has been reported in both investigations that exposure of $\mathrm{SO}_{2}$ at high temperatures first at $\left(350{ }^{\circ} \mathrm{C}\right.$ vs $\left.190{ }^{\circ} \mathrm{C}\right)$ and later at $\left(250{ }^{\circ} \mathrm{C}\right.$ vs $150{ }^{\circ} \mathrm{C}$ ) showed sulfur storage in large amount. In another study [58] unspecified $\mathrm{Cu}$-zeolite showed the opposite trend, where exposure of $\mathrm{SO}_{3}$ at low sulfation temperature (Setting temperature for results: $200{ }^{\circ} \mathrm{C}, 300$ ${ }^{\circ} \mathrm{C}$ and $400{ }^{\circ} \mathrm{C}$ ) reported large amount of sulfur storage. However, it has also been investigated in same study; the catalyst activity showed the larger decline at high temperatures after the sulfation.
It was investigated that sulfur storage impacted with the different forms of sulfur $[57,58]$ both reported that the sulfur storage as a result of $\mathrm{SO}_{3}$ exposure is more than $\mathrm{SO}_{2}$ exposure. Also, it has been observed that during sulfation period, the sulfur storage at the present of $\mathrm{NH}_{3}$ is more affected than the absence of $\mathrm{NH}_{3}[56,59,63]$.

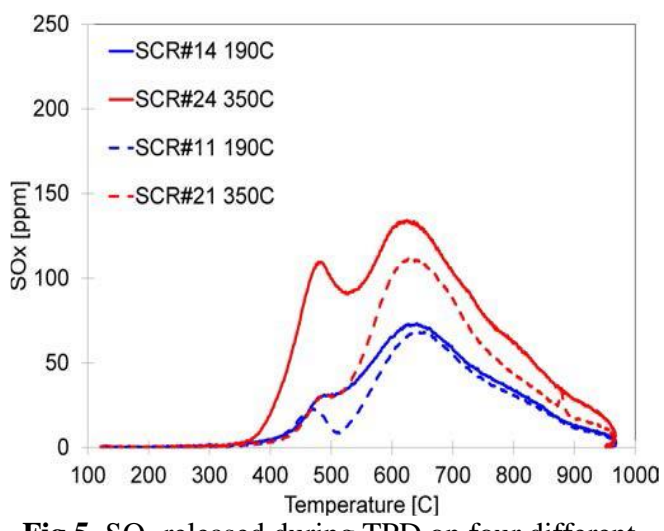

Fig.5. $\mathrm{SO}_{\mathrm{x}}$ released during TPD on four different sulfur saturated chabazite structure SCR catalysts. Sulfur saturation of $\mathrm{SO}_{2}$ and $\mathrm{SO}_{3}$ was shown by solid lines and only $\mathrm{SO}_{2}$ by dotted lines. At the temperature of $190{ }^{\circ} \mathrm{C}$ and $350{ }^{\circ} \mathrm{C}$, blue and red lines were sulfur saturated respectively

Temperature programmed desorption (TPD) was used to investigate the sulfur storage on the four different sulfur saturated chabazite structure SCR catalysts. Fig. 5 showed the TPD diagram. Sulfur saturation of $\mathrm{SO}_{2}$ and $\mathrm{SO}_{3}$ was shown by solid lines and only $\mathrm{SO}_{2}$ by dotted lines. At the temperature of $190{ }^{\circ} \mathrm{C}$ and $350{ }^{\circ} \mathrm{C}$, blue and red lines were sulfur saturated respectively. At DOC, $\mathrm{SO}_{2}$ was oxidized into $\mathrm{SO}_{3}$, therefore the ratio of $\mathrm{SO}_{3}$ and $\mathrm{SO}_{2}$ largely depends upon the sulfation temperature. At high sulfation temperatures, significant amount of $\mathrm{SO}_{3}$ can be estimated. Two peaks have been shown in all TPD curves first at ca $480{ }^{\circ} \mathrm{C}$ and second at ca $650{ }^{\circ} \mathrm{C}$. It has been concluded that for both $\mathrm{SO}_{3}$ and $\mathrm{SO}_{2}$, sulfur storage was much more after sulfation as compared to only $\mathrm{SO}_{2}$. Furthermore, at high temperature $\left(350{ }^{\circ} \mathrm{C}\right)$, more sulfur storage occurs after sulfation than the low temperature $\left(190^{\circ} \mathrm{C}\right)[57]$. 


\subsubsection{Regeneration of sulfated cu-zeolite}

It has been reported that different type of ways showed different results while regenerating the sulfated $\mathrm{Cu}$-zeolites. Sulfation of $200 \mathrm{ppm}$ of $\mathrm{SO}_{2}$ at $130{ }^{\circ} \mathrm{C}$ for 3 hours was carried out to regenerate the $\mathrm{Cu} / \mathrm{SAPO}-34$ catalyst [46]. Regeneration of a $\mathrm{Cu} / \mathrm{SAPO}-34$ catalyst was performed for 12 hours by varying temperatures at 300, 400, 500,600 and $700{ }^{\circ} \mathrm{C}$. Up to temperature of $600{ }^{\circ} \mathrm{C}$, regenerated catalyst showed the limited recovery in NO removal efficiency. The regeneration of catalyst was fully observed at $600{ }^{\circ} \mathrm{C}$.

Various sulfation methods were used to investigate the regeneration of $\mathrm{Cu}$-chabazite catalyst [57]. It has been observed that the regeneration of $\mathrm{SO}_{2}$ aged catalyst at low temperature $\left(200{ }^{\circ} \mathrm{C}\right)$ was easier than the high temperature $\left(400{ }^{\circ} \mathrm{C}\right)$ aged. Furthermore, during the comparison of $\mathrm{SO}_{2}$ aged catalyst, with and without the presence of $\mathrm{NH}_{3}$, no difference has been observed in the regeneration of catalyst. A repeated activity test has been performed for the regeneration of $\mathrm{Cu} / \mathrm{SSZ}-13$ catalyst at temperatures in between of $100{ }^{\circ} \mathrm{C}$ to $400{ }^{\circ} \mathrm{C}$ [56]. Catalyst with exposure of $\mathrm{S}_{2}$ poisoning ( $30 \mathrm{ppm}$ ) was investigated at temperature of $300{ }^{\circ} \mathrm{C}$ for 1.5 hours. Eight activity tests have been performed to obtain the stable activity. It has been observed from the experiment that by repeating the activity test some activity was recovered but not achieving the fully regeneration of catalyst.

$\mathrm{Cu}$-chabazite catalyst was used to investigate the regeneration also named as chemical deSO $\mathrm{S}_{\mathrm{x}}$ method [21]. For reducing the environmental problems, low concentration of reductant such as $\mathrm{NH}_{3}$, $\mathrm{NO}_{\mathrm{x}}+\mathrm{NH}_{3}, \mathrm{C}_{2} \mathrm{H}_{6}$ and $\mathrm{n}-\mathrm{C}_{12} \mathrm{H}_{26}$ was used. By using this technique, it has been observed that at lower regeneration temperatures, recovery of $\mathrm{NO}_{\mathrm{x}}$ conversion activity and removal of sulfur was achieved.

\subsubsection{Characterizations of sulfated cu- zeolites}

Sulfated catalyst has been characterized in many studies. $\mathrm{N}_{2}$ adsorption is used to determine to surface area and its pore volume. It has been observed that after the sulfation both surface area and pore volume were decreased [20-22, 56]. But after regeneration both could be recovered [22]. Xray flouorescence (XRF) was used to investigate the framework of SAPO-34 and it has been observed that it was not changed after the poisoning of $\mathrm{SO}_{2}$. This recommends that sulfur only affects the copper sites of catalyst not the framework of zeolite [64].

Analysis of Inductively coupled plasma (ICP) and X-ray photoelectron spectroscopy (XPS) were used to investigate the sulfur distribution, it has been found that, sulfur was uniformly distributed only if the catalyst was saturated [57, 61]. More sulfur has been observed at the catalyst inlet as compared to outlet, if the catalyst was not saturated properly $[56,58]$.

Numerous methods have been reported to determine the type in which storage of sulfur is taken place over the sulfated $\mathrm{Cu}$-zeolite. It has been observed that there are two primary sulfur species such as ammonium sulfates and copper sulfates depending upon the sulfation conditions [46, 58, 59]. Formation of ammonium and copper sulfates was studied on the $\mathrm{Cu} / \mathrm{SAPO}-34$ catalyst [65]. It has been observed that ammonium and copper sulfates are exchangeable depends upon the availability of $\mathrm{NH}_{3}$. Ammonium sulfates can be formed by $\mathrm{NH}_{3}$ exposure of copper sulfates over the catalyst. During the absence of $\mathrm{NH}_{3}$ the usage of ammonium sulfates upon the NO exposure behaves as SCR reactant. However, this reaction is much slow as compared to normal SCR reaction. Also, copper sulfates are formed when the SCR reactants are ammonium sulfates. 


\subsubsection{Sulfur posioning mechanism on cu-} zeolite

$\mathrm{Cu} / \mathrm{SSZ}-13$ catalyst was used to investigate the active sites. Diffuse reflectance infrared Fourier transform spectroscopy (DRIFTS) with $\mathrm{NH}_{3}$ probing was used to identify the two cu-sites. In SCR reactions both sites were active but in oxidation reactions only one site was active. Furthermore, also their responses towards sulfur poisoning and hydrothermal aging were investigated. In oxidation reaction the active site was disappeared and in SCR reaction, both active site was reduced extensively [66]. After $\mathrm{SO}_{2}$ poisoning, the activity loss over the $\mathrm{Cu} / \mathrm{SAPO}-34$ catalyst was described by the reduction in the active sites of $\mathrm{Cu}$-zeolite because of the sulfur present in the catalyst. It has been observed that the NO conversion and sulfur exposure showed inverse relationship if sulfur exposure was increased then $\mathrm{NO}$ conversion was decreased [64].

\subsection{Behavior of sulfur over SCR catalysts with different temperatures (Recent developments)}

$\mathrm{SO}_{2}$ poisoning of $\mathrm{NH}_{3}-\mathrm{SCR}$ was evaluated by Yasser [67] over Cu-SAPO-34, mainly to investigate stored $\mathrm{S}$ forms/states and the effect of them on reduction activity of low-temperature NOx. There were two types of primary sulfur species found, and it was observed that they both were interchangeable depending upon the availability or the absence of $\mathrm{NH}_{3}$. Cu sulfate species as well as Ammonium sulfate species could be found in one case, while for the other case only $\mathrm{Cu}$ sulfate species would be found. $\mathrm{Cu}$ sulfate was available in three different states/forms when ammonia was absent, this was found out by three desorption features while conducting experiments of TPD (temperature programmed desorption). NO adsorption's DRIFTS (Diffuse reflectance infrared Fourier transform spectroscopy) was utilized for the investigation of accessibility and nature of
$\mathrm{Cu}$ species prior to and after the sulfate formation, subject to no intrusion by ammonium sulfate; the acquired states showed that the sulfur had completely blocked $\mathrm{Cu}^{2+}$ within the six membered rings, and nature of $[\mathrm{CuOH}]^{+}$near the eightmembered ring had changed. On analyzing impacts of dissimilar states of $S$ on reduction activity of $\mathrm{NO}_{\mathrm{x}}$, ammonium sulfate having low-temperature was found to have the greatest effect on the loss of performance. Moreover, the data demonstrated that ammonium sulfate have tendency to work as SCR reactant, quite similar to the system incorporating ammonium nitrate. Decomposition of Ammonium sulfate starts at temperatures which can be as small as 300-350 ${ }^{\circ} \mathrm{C}$, in contrast to that higher temperatures $\left(>480{ }^{\circ} \mathrm{C}\right)$ were required for desorption of other $\mathrm{S}$ containing species as illustrated in fig 6 .

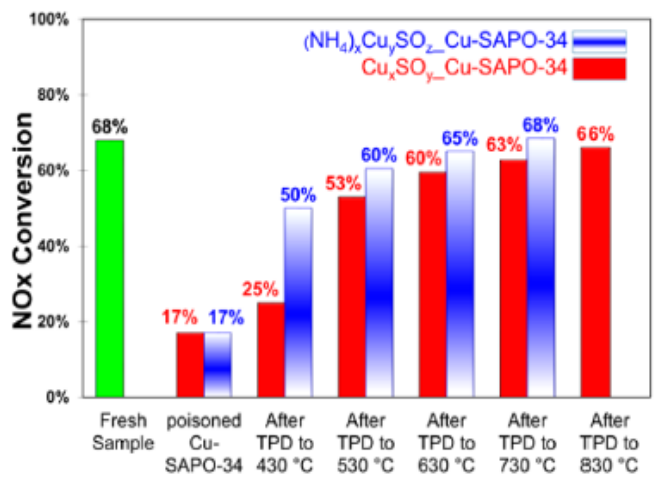

Fig. 6. SCR changing at $210{ }^{\circ} \mathrm{C}$ along with the raw sample, during existence of $\mathrm{SO}_{2}$ quantity50 ppm, sample on which $\mathrm{Cu}_{\mathrm{x}} \mathrm{SO}_{\mathrm{y}}$ was materialized and later brought to temperatures of 430, 530, 630,

730 , and $830{ }^{\circ} \mathrm{C}$ in presence of $\left(\mathrm{NH}_{4}\right)_{x}$ or $\mathrm{N}_{2}$

This seems promising, as reaction of $\mathrm{NH}_{3}$ can occur in the presence of catalyst with reabsorbed sulfur to form ammonium sulfate, having tendency to decompose at smaller temperatures as compared to other forms of sulfate.

Sandra [68] observed the impacts of Sulphur experimentally, upon lowtemperature behavior of $\mathrm{Cu}-\mathrm{SSZ}-13 \mathrm{SCR}$ catalyst. The outcomes of exposure 
temperature of sulfur, and impacts of $\mathrm{NO}_{\mathrm{x}} / \mathrm{NO}_{2}$ ratio, are taken into consideration and a comparison of two separate regeneration temperatures is performed. Besides that, samples of catalyst taken from catalyst affected by an engine-aged are analyzed. Exposition temperature of $\mathrm{SO}_{2}$ possesses important effect on $\mathrm{Cu}-\mathrm{SSZ}-13$ catalyst deactivation. The most severe deactivation is caused due to lowest Sulphur exposure temperature $\left(220{ }^{\circ} \mathrm{C}\right)$, whereas during the highest temperature of Sulphur exposure $\left(400{ }^{\circ} \mathrm{C}\right)$ deactivation of the lowest degree is observed as demonstrated in figure 7.

Yulong [69] investigated the hydrothermal aging at prominent temperature. Not the same as the reversible hindrance of SO2 harming that happens at truncated temperatures, because of the demolition of the zeolite structure the sulfur harming at prominent temperature is longlasting.

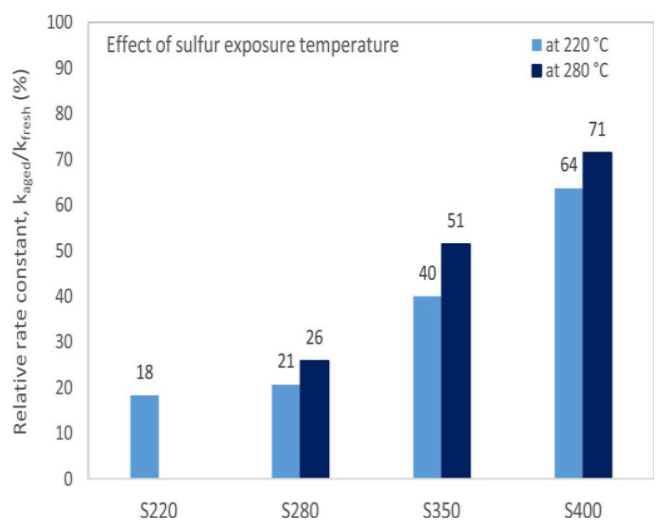

Fig. 7. Relative rate constants for catalyst exposed at different temperature ranges. Note that, the sample which was brought at $220^{\circ} \mathrm{C}$ to $\mathrm{SO} 2 \mathrm{had}$ no test at $280{ }^{\circ} \mathrm{C} .5$ vol.-\% H2O, 10 vol.-\% O2 1000

vol.-ppm NH3, 1000 vol.-ppm NO, 120,000

$\mathrm{h}^{-1}$ GHSVduring the test of activity.

In Figure 8 the benchmark $\mathrm{SCR} \mathrm{NO}_{\mathrm{x}}$ and $\mathrm{NH}_{3}$ transformation exercises of $\mathrm{HA}-\mathrm{Cu}-$ SSZ-13, FR-Cu-SSZ-13 and SA-Cu-SSZ-13 chemical agents are portrayed by means of a portion of temperature as of 150 to $550{ }^{\circ} \mathrm{C}$. It has been observed the new Cu-SSZ-13 showed the finest NH3-SCR action on entire temperature ranges. The decrease action of
NO weakened somewhat for the Cu-SSZ-13 afterwards it was hydrothermally aged at 750 ${ }^{\circ} \mathrm{C}$ aimed at $32 \mathrm{~h}$. For the SA-Cu-SSZ-13 test critical loss of not any decreased movement was watched that was hydrothermally aged within the sight of $100 \mathrm{ppm} \mathrm{SO}$. Throughout hydrothermal aging proposed deactivation of $\mathrm{Cu}-\mathrm{SSZ}-13$ was significantly more extreme within the sight of $\mathrm{SO}_{2}$. The $\mathrm{NH}_{3}$ change is a lot advanced than any transformation due to unselective $\mathrm{NH}_{3}$ oxidation. When the temperatures over $450{ }^{\circ} \mathrm{C}$ and $300{ }^{\circ} \mathrm{C}$ aimed at the SA-Cu-SSZ-13 and HA-Cu-SSZ-13 tests, the uncritical $\mathrm{NH} 3$ oxidation was fundamentally in charge for the decomposition of not any adaptation at prominent temperatures.

Meiqing [70] investigated the impact of SO3 poisoning over $\mathrm{Cu} / \mathrm{SAPO}-34$.

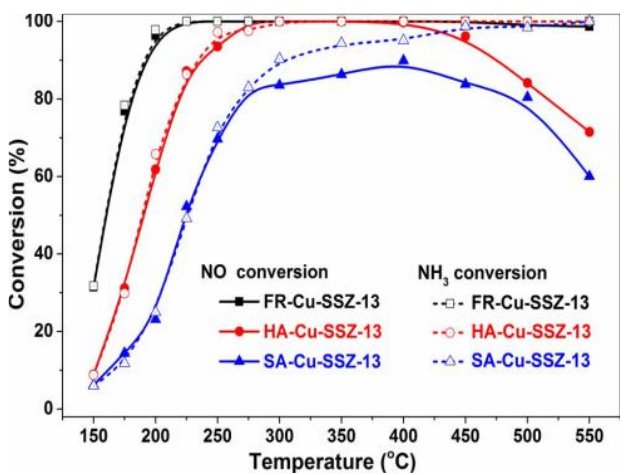

Fig. 8. $\mathrm{NO}$ and $\mathrm{NH}_{3}=500$ ppm, 5 vol. $\% \mathrm{O} 2,5$ vol $\% \mathrm{H} 2 \mathrm{O}$, equilibrium $\mathrm{N} 2$. GHSV $=400,000 \mathrm{~h}^{-1}$. $\mathrm{NO}_{x}$ and $\mathrm{NH}_{3}$ change of HA-Cu-SSZ-13, FR-CuSSZ-13 and SA-Cu-SSZ-13 catalysts below normal SCR circumstances.

Fig. 9 The reaction of $\mathrm{NH}_{3}$ SCR consisting sulfated and fresh $\mathrm{Cu} / \mathrm{SAPO}-34$ catalysts is shown. In comparison to $\mathrm{F}-\mathrm{Cu}$, declines in NOx conversion are seen of sulfated catalysts when $\mathrm{SO}_{3}$ to $\mathrm{SO}_{x}$ ratio increases. Remarkably, throughout the whole temperature region, $\mathrm{S}-20-\mathrm{Cu}$ was found to be least active catalyst of all kinds of sulfated samples. Unsulfured catalysts having $600 \mathrm{C}$ (7 ppm) has the highest $\mathrm{N} 2 \mathrm{O}$ formation on it, and the sulfation action results in reduction of the formation of $\mathrm{N}_{2} \mathrm{O}$ by 1 to 2 ppm. (Fig. $8 b)$. 
In this work [71] the deactivation conducts and procedure of a $\mathrm{Cu}-\mathrm{SAPO}-34$ catalyst by reactor trial and DFT computations was studied. The dignified steady state of NOx changes for the new catalyst can be determined from the figure $1 \mathrm{~A}$, after introduction to $\mathrm{SO}_{2}$, and subsequently regeneration at $550{ }^{\circ} \mathrm{C}$. After introduction of $\mathrm{SO} 2,1.5 \mathrm{ppm}$ portion was added to the SCR-feed, $\mathrm{SO}_{2}$ concentration is also presumed in automotive diesel exhaust, for $8 \mathrm{~h}$ we detained the new catalyst at 300 ${ }^{\circ} \mathrm{C}$, Execution at $550{ }^{\circ} \mathrm{C}$ for $1 \mathrm{~h}$ in SCR-feed gas in the absence of $\mathrm{SO}_{2}$ for renewal of the catalyst. When $\mathrm{SO}_{2}$ was introduced it resulted in significantly lesser steady state $\mathrm{NO}_{\mathrm{x}}$ changes in the temperature variety $150-300$ ${ }^{\circ} \mathrm{C}$.

For all intents and practical purposes after probing $\mathrm{SO}_{2}$ deactivation, it is frequently convenient towards quicken the $\mathrm{SO}_{2}$-harming by rising the concentration of $\mathrm{SO}_{2}$ and
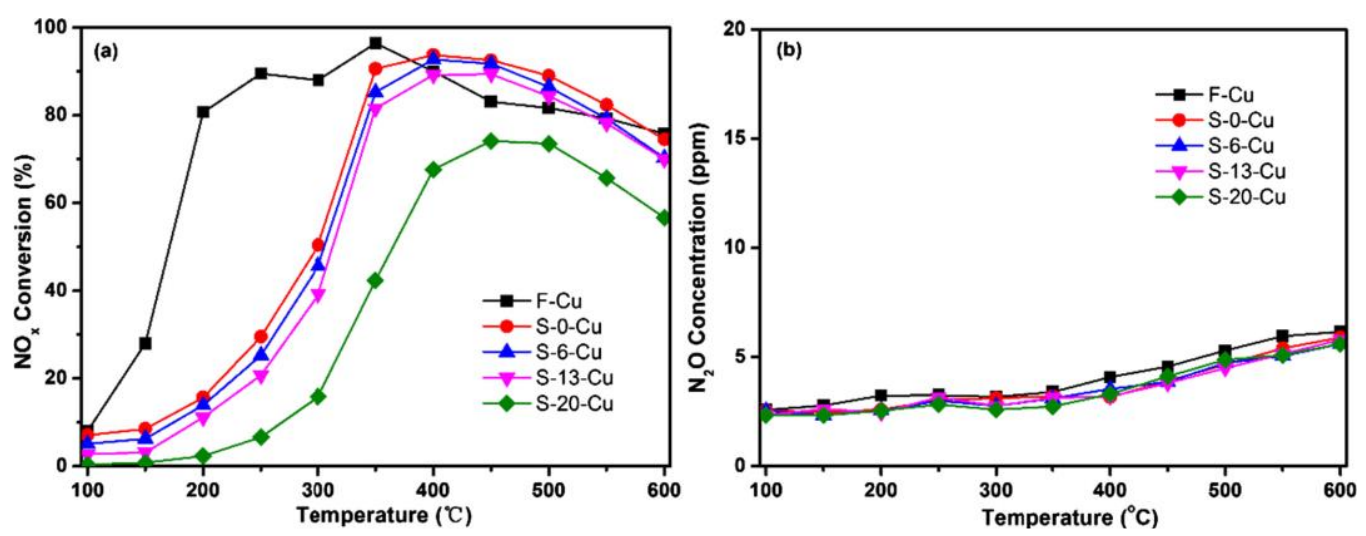

Fig. 9. NOx conversion as a relation pertaining to reaction temperature on the raw and sulfated catalysts $\mathrm{S}-0-\mathrm{Cu}=50 \mathrm{ppm}$ of $\mathrm{SO}_{2}$ for $16 \mathrm{~h}, \mathrm{~S}-6-\mathrm{Cu}=50 \mathrm{ppm}$ of $\mathrm{SO}_{\mathrm{x}}\left(6 \% \mathrm{SO}_{3}\right)$ for $16 \mathrm{~h}, \mathrm{~S}-13-\mathrm{Cu}=50 \mathrm{ppm}$ of $\mathrm{SO}_{\mathrm{x}}$ $\left(13 \% \mathrm{SO}_{3}\right)$ for $16 \mathrm{~h}$ and $\mathrm{S}-20-\mathrm{Cu} 50 \mathrm{ppm}$ of $\mathrm{SO}_{\mathrm{x}}\left(20 \% \mathrm{SO}_{3}\right)$ for $16 \mathrm{~h}$ (a) and emergence of $\mathrm{N} 2 \mathrm{O}$ in course of NH3 SCR reaction over the fresh and sulfated catalysts (b)The execution of reaction was done with a mixture containing NOx $500 \mathrm{ppm}, \mathrm{NH} 3500 \mathrm{ppm}, 7 \% \mathrm{CO} 2,5 \% \mathrm{O} 2,3 \% \mathrm{H} 2 \mathrm{O}$, and balance $\mathrm{N} 2$ owing to GHSV $=72,000 \mathrm{~h}^{-1}$ proportionally abbreviating the exposure period. The outcomes are then construed in appellation of the overall $\mathrm{SO}_{2}$ exposure, considered as the formation of the $\mathrm{SO}_{2}$ fractional pressure and the exposure period, instead of the $\mathrm{SO}_{2}$ concentration. This elucidation needs that a straight proportionality occurs and the exposure period and $\mathrm{SO}_{2}$ concentration, in a way that dual framework can be climbed with respect to $\mathrm{SO}_{2}$-harming. By estimating the outcomes of the non-accelerated $\mathrm{SO}_{2}$ introduction scalability was scrutinized for example introduction to $1.5 \mathrm{ppm} \mathrm{SO}_{2}$, towards the outcomes from a catalyst revealed to an enhanced $\mathrm{SO}_{2}$ introduction. Meant for the enhanced $\mathrm{SO}_{2}$ introduction, the concentration of $\mathrm{SO}_{2}$ was enlarged by a number 10 and the introduction time was harmoniously reduced. 

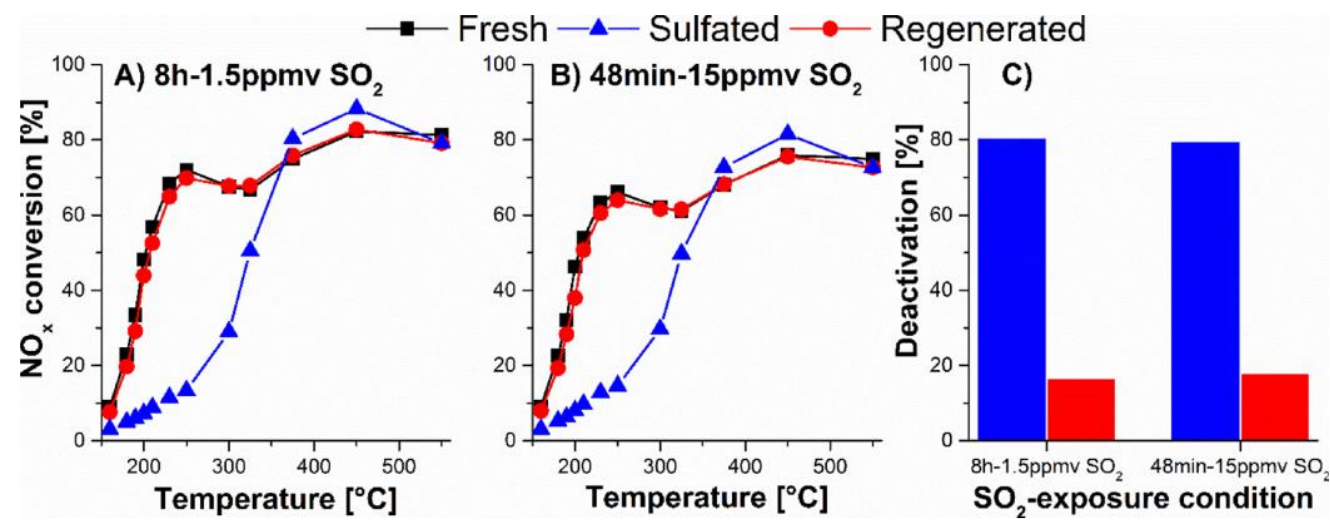

Fig. 10(A) NOx as purpose of temperature exhibits its conversion for the Cu-SAPO-34 catalyst earlier and later experience to $1.5 \mathrm{ppm}(\mathbf{B})$ The temperature for the Cu-SAPO-34 by NOx conversion catalyst earlier and later exposure to $15 \mathrm{ppm}(\mathbf{C})$ After deactivation the sulfated (blue inns) and recovered (red inns) express the $\mathrm{Cu}-\mathrm{SAPO}-34$ catalysts assessed at $180{ }^{\circ} \mathrm{C}$, afterwards introduction to $1.5 \mathrm{ppm} \mathrm{SO}_{2}$ aimed at $8 \mathrm{~h}$ and $15 \mathrm{ppm} \mathrm{SO}_{2}$ aimed at $48 \mathrm{~min}$.

Therefore, in the $\mathrm{SO}_{2}$ in SCR-feed gas was exposed to $15 \mathrm{ppm}$ for $48 \mathrm{~min}$ at $300{ }^{\circ} \mathrm{C}$. Figure10B illustrates the stable state of $\mathrm{NO}_{\mathrm{x}}$ changes earlier and later the accelerated $\mathrm{SO}_{2}$ exposure, and later $1 \mathrm{~h}$ renewal at $550{ }^{\circ} \mathrm{C}$ inside SCR-feed gas. The outward form of the NOx changes is for the enhanced $\mathrm{SO}_{2}$ introduced catalyst in Fig. 10B, it is very analogous to the revealed inside figure 10A, figure10B.

Illustrates the NOx vicissitudes of the new catalyst is somewhat underneath those of the new catalyst in figure 10A which is because of slight variances in the catalyst loads. Hence, to check the resemblance of the impact of the enhanced and non-enhanced $\mathrm{SO}_{2}$ exposure circumstances on the SCR presentation of the catalyst, the deactivation (assessed at $180{ }^{\circ} \mathrm{C}$ ) after $\mathrm{SO} 2$ experience and renewal are illustrated in Figure 10C. After both behaviors the degree of deactivation is similar with overall deactivations of 80 and $79 \%$ and permanent deactivations of $16 \%$ and $18 \%$. For the same total exposure, it signifies that the deactivation is identical, here $\mathrm{SO}_{2}$ concentration and revelation period are scalable.

\section{Summary}

Vanadium based catalysts can be impacted by sulfur exposure in different ways. If $\mathrm{NH}_{3}$ is absence during poisoning at high temperatures, $\mathrm{NO}_{\mathrm{x}}$ activity can be increased. If $\mathrm{NH}_{3}$ is present during the sulfur exposure of catalyst, formation of ammonium sulfates can be produced, which ultimately results the physical deactivation of catalyst. The decomposition of ammonium sulfates occurs when the temperature in between $280-350{ }^{\circ} \mathrm{C}$ and also by increasing the temperature regeneration of catalyst can be achieved. Consequently, the main problem occurs with vanadium-based catalyst when the high level of sulfur is exposed at low temperatures. Thus, the catalyst temperature never exceeds the decomposition temperature.

$\mathrm{NO}_{\mathrm{x}}$ activity can be deactivated with sulfur exposure of $\mathrm{Cu}$-zeolites catalysts. $\mathrm{SO}_{3}$ poisoning is capable to produce severe deactivation of catalyst activity, high sulfur storage and very hard to regenerate the catalyst as compared to $\mathrm{SO}_{2}$ poisoning. $\mathrm{SO}_{3}$ and $\mathrm{SO}_{2}$ poisoning are not reliable with impact of temperature. It has been recommended that, at high temperature chemisorption occurs over the catalyst surface and at low temperature formation of ammonium sulfate and physical adsorption 
occurs. Two sulfated species were observed while characterizing the sulfated $\mathrm{Cu}$-zeolite named as ammonium and copper sulfates. It has been recommended that sulfated species is the main cause of deactivation which ultimately blocks the active $\mathrm{Cu}$-sites, either by the formation of ammonium and copper sulfates that blocks the active sites of catalyst physically or by adsorption of sulfur species. Furthermore, sulfur poisoning does not affect the zeolite structure, but it only affects the active sites of copper. Sulfated catalysts have been regenerated in a lean environment by increasing exposure temperature about to $600-700{ }^{\circ} \mathrm{C}$.

\section{ACKNOWLEDGEMENT}

I would like to thank the National Key R\&D Program of China (2016YFC0205200) and the Ministry of Industry and Information Technology of Marine Low-Speed Engine Project Phase - I for supporting this work.

\section{REFERENCES}

[1] P. Geng, "Effects of alternative fuels on the combustion characteristics and emission products from diesel engines," A review. Renewable and Sustainable Energy Reviews, Vol. 71, 2017, pp. 523-534.

[2] N. Hu, P. Zhou, and J. Yang, "Reducing emissions by optimising the fuel injector match with the combustion chamber geometry for a marine medium-speed diesel engine," Transportation Research Part D: Transport and Environment, Vol. 53, 2017, pp. 1-16.

[3] C. Zhanga, C. Suna, M. Wua, and K. Lub, "Optimization design of SCR mixer for improving deposit performance at low temperatures," Fuel Vol. 237, 2019, pp. 465474.

[4] W. Chen, H. Fali, L. Qin, H. Jun, B. Zhao, T. Yangzhe, and Y. Fei, "Mechanism and Performance of the SCR of NO with NH3 over Sulfated Sintered Ore Catalyst." Catalysts Vol. 9, 2019, pp. 90-101.

[5] C. Baukal, "Everything you need to know about NOx: Controlling and minimizing pollutant emissions is critical for meeting air quality regulations," Metal finishing, Vol. 103, 2005, pp. 18-24.

[6] Gu, "A potentially over estimated compliance method for the Emission control Areas,"
Transportation Research Part D, Vol. 55, 2017, pp. 51-66.

[7] A. Aberg, A. Widd, J. Abildskov, and J.K. Huusom, "Parameter estimation and analysis of an automotive heavy-duty scr catalyst model," Chemical Engineering Science, Vol. 161, 2017, pp. 167-177.

[8] E. Codan, S. Bernasconi, and H. Born, Imo III emission regulation: Impact on the turbocharging system, CIMAC Congress, 2010.

[9] R. Geertsma, R. Negenborn, K. Visser, M. Loonstijn, and J. Hopman, "Pitch control for ships with diesel mechanical and hybrid propulsion: Modeling, validation and performance quantification," Applied Energy, Vol. 206, 2017, pp. 1609-1631.

[10] L. XR, "Combustion and emission characteristics of a lateral swirlcombustion system for DI diesel engines under low excess air ratio conditions," Fuel, Vol. 186, 2016, pp. 672-80.

[11] C. K, P. J, and K. SL, "A comparison of Reactivity Controlled Compression Ignition (RCCI) and Gasoline Compression Ignition (GCI) strategies at high load, low speed conditions," Energy Convers Manag, Vol. 127, 2016, pp. 324-41.

[12] A. Güthenke, D. Chatterjee, M. Weibel, M. Krutzsch, B. Kocí, P. Marek, M. Nova, and E. Tronconi, "Current status of modeling lean exhaust gas aftertreatment catalysts', Advances in Chemical Engineering, Vol. 33(07), 2007.

[13] M. Koebel, M. Elsener, and M. Kleemann, "Urea-SCR: A promising technique to reduce NOx emissions from automotive diesel engines," Catalysis Today, Vol. 59(3/4), 2000, pp. 335-345.

[14] Oliveira, "Modeling of NOx emission factors from heavy and light-duty vehicles equipped with advanced after treatment systems," Energy Conversion and Management, Vol. 52, 2011, pp. 2945-2951.

[15] S.S. P, "A Review on Selective Catalytic Reduction (SCR)-A Promising Technology to mitigate NOx of Modern Automobiles," International Journal of Applied Engineering Research, Vol. 13, 2018, pp. 5-9.

[16] F. Birkhold, "Modeling and simulation of the injection of urea-water solution for automotive Scr deNox-systems," Applied Catalysis B: Environmental, Vol. 170, 2007, pp. 119-127.

[17] C. Choi, "Numerical Analysis of Urea Decomposition with Static Mixers in Marine SCR System," Journal of Clean Energy Technologies, Vol. 3(1), 2015, pp. 39-42. 
[18] Y. Xi, N. A. Ottinger and G. Liu, "New insights into sulfur poisoning on a vanadia SCR catalyst under simulated diesel engine operating conditions," Applied Catalysis B: Environmental, Vol. 64, 2014, pp. 1-9.

[19] I. Nova and E. Tronconi, "Urea-SCR Technology for deNOx After Treatment of Diesel Exhausts," Springer, 2014.

[20] B. K. Yun, and M.Y. Kim, "Modeling the selective catalytic reduction of NOx by ammonia over a vanadium-based catalyst from heavy duty diesel exhaust gases," Applied Thermal Engineering, Vol. 50, 2013, pp. 152-158.

[21] H. L. Fang, H.F.M, and DaCosta, "Urea thermolysis and NOx reduction with and without SCR catalysts." Appl. Catal. B: Environ, Vol. 46, 2013, pp. 14-34.

[22] X. Liu, X. Wu, D. Weng and Z. Si, "Durability of $\mathrm{Cu} / \mathrm{SAPO}-34$ catalyst for NOx reduction by ammonia: Potassium and sulfur poisoning," Catalysis Communications, Vol. 59, 2014, pp. 35-39.

[23] A. Kumar, M. A. Smith, K. Kamasamudram, N. W. Currier and Y. Aleksey, "Chemical deSOx: An effective way to recover $\mathrm{Cu}$ zeolite SCR catalysts from sulfur poisoning," Catalysis Today, Vol. 267, 2016, pp. 10-16.

[24] D. W. Brookshear, J.-g. Nam, K. Nguyen, T. J. Toops and A. Binder, "Impact of sulfation and desulfation on NOx reduction using $\mathrm{Cu}$ chabazite SCR catalysts," Catalysis Today, Vol. 258, 2015, pp. 359-366.

[25] D. Chatterjee and K. Rusch, "Urea-SCR Technology for deNOx After Treatment of Diesel Exhausts," Springer, 2014.

[26] J. Wang, H. Zhao, G. Haller and Y. Li, "Recent advances in the selective catalytic reduction of $\mathrm{NOx}$ with $\mathrm{NH}_{3}$ on $\mathrm{Cu}-\mathrm{Ch}$ abazite catalysts," Applied Catalysis B: Environmental, Vol. 202, 2017, pp. 346-354.

[27] K. Leistner, O. Mihai, K. Wijayanti, A. Kumar, K. Kamasamudram, N. W. Currier, A. Yezerets and L. Olsson, "Comparison of $\mathrm{Cu} / \mathrm{BEA}, \mathrm{Cu} / \mathrm{SSZ}-13$ and $\mathrm{Cu} / \mathrm{SAPO}-34$ for ammonia-SCR reactions," Catalysis Today, Vol. 258, 2015, pp. 49-55.

[28] Y. Peng, et al., "Comparison of $\mathrm{MoO}_{3}$ and $\mathrm{WO}_{3}$ on arsenic poisoning $\mathrm{V}_{2} \mathrm{O}_{5} / \mathrm{TiO}_{2}$ catalyst: DRIFTS and DFT study," Applied Catalysis. B, Vol. 181, 2016, pp. 692-698.

[29] S. M. Lee, K.H. Park, and S.C. Hong, $\mathrm{MnOx} / \mathrm{CeO} 2-\mathrm{TiO} 2$ mixed oxide catalysts for the selective catalytic reduction of NO with $\mathrm{NH}_{3}$ at low temperature," Chemical Engineering Journal, Vol. 13, 2012, pp. 323331.

[30] Y. Qiu, et al., "The monolithic cordierite supported V2O5-MoO3/TiO2catalyst for
NH3-SCR.," Chemical Engineering Journal, Vol. 294, 2016, pp. 264-272.

[31] M. Shimokawabe, "SCR of NO by DME over $\mathrm{Al} 2 \mathrm{O} 3$ based catalysts: Influence of noble metals and $\mathrm{Ba}$ additive on lowtemperature activity," Catalysis Today, Vol. 164, pp. 480-483.

[32] S. S. Kim, "Enhanced catalytic activity of $\mathrm{Pt} / \mathrm{Al}_{2} \mathrm{O}_{3}$ on the $\mathrm{CH}_{4}$ SCR," Journal of Industrial and Engineering Chemistry, Vol. 18, 2012, pp. 272-276.

[33] L.M. Yu, et al., "Enhanced $\mathrm{NO}_{\mathrm{x}}$ removal performance of amorphous $\mathrm{Ce}-\mathrm{Ti}$ catalyst by hydrogen pretreatment. Journal of Molecular," Catalysis A, Vol. 423, 2016, pp. 371-378.

[34] X. Liu, et al., "Probing $\mathrm{NH}_{3}-\mathrm{SCR}$ catalytic activity and $\mathrm{SO}_{2}$ resistance over aqueousphase synthesized Ce-W@ $\mathrm{TiO}_{2}$ catalyst," Journal of Fuel Chemistry and Technology, Vol. 44, 2016, pp. 225-231.

[35] C. K. Seo, et al., "Effect of $\mathrm{ZrO}_{2}$ addition on de-NO $\mathrm{NO}_{\mathrm{x}}$ performance of Cu-ZSM-5 for SCR catalyst," Chemical Engineering Journal, Vol. 191, 2012, pp. 331-340.

[36] P. NakhostinPanahi, "Comparative study of ZSM - 5 supported transition metal $(\mathrm{Cu}, \mathrm{Mn}$, $\mathrm{Co}$, and $\mathrm{Fe}$ ) nanocatalysts in the selective catalytic reduction of $\mathrm{NO}$ with $\mathrm{NH}_{3}$," Environmental Progress and Sustainable Energy, Vol. 36, 2017, pp. 1049-1055.

[37] X. L. Tang, et al., "Low-temperature SCR of NO with NH3 over AC/C supported manganese-based monolithic catalysts," Catalysis Today, Vol. 126, 2007, pp. 406411.

[38] B. C. Huang, et al., "Low temperature SCR of $\mathrm{NO}$ with $\mathrm{NH}_{3}$ over carbon nanotubes supported vanadium oxides," Catalysis Today, Vol. 126, 2007, pp. 279-283.

[39] C. H. Bartholomew, "Mechanisms of catalyst deactivation," Applied Catalysis A: General, Vol. 212, 2001. pp. 17- 60.

[40] M. V. Twigg, "Progress and future challenges in controlling automotive exhaust gas emissions," Applied Catalysis B: Environmental, Vol. 70, 2007, pp. 2-15.

[41] A. Varna, A.C. Spiteri, and Y.M. Wright, "Experimental and numerical assessment of impingement and mixing of urea-water sprays for nitric oxide reduction in diesel exhaust," Applied Energy, Vol. 157, 2015, pp. 824-837.

[42] S. Grout, J.B. Blaisot, and K. Pajot, "Experimental investigation on the injection of an urea-watersolution in hot air stream for the SCR application: Evaporation and spray/wall interaction," Fuel, Vol. 106, 2013, pp. 166-177. 
[43] MAN B\&W. MAN emission project guide: MAN B\&W two-stroke marine engines. $E U$ : MAN B\&W press 2013.

[44] R. M. Heck, R. J. Farrauto and S. T. Gulati, Catalytic air pollution control Commercial Technology, 3ed., New Yersey: John Wiley \& Sons, Inc., 2009.

[45] Y. H. Shi, H. Shu, Y.-H. Zhang, H.-M. Fan, Y.-P. Zhang and L.-J. Yang, "Formation and decomposition of NH4HSO4 during selective catalytic reduction of $\mathrm{NO}$ with $\mathrm{NH} 3$ over V2O5-WO3/TiO2 catalysts," Fuel Processing Technology, Vol. 150, 2016, pp. 141-147.

[46] L. Zhang, D. Wang, Y. Liu, K. Kamasamudram, J. Li and W. Epling, "SO2 poisoning impact on the NH3-SCR reaction over a commercial Cu-SAPO-34 SCR catalyst," Applied Catalysis B: Environmental, Vol. 157, 2014, pp. 371-377.

[47] R. Q. Long, R. T. Yang and R. Chang, "Low temperature selective catalytic reduction (SCR) of $\mathrm{NO}$ with $\mathrm{NH}_{3}$ over $\mathrm{Fe}-\mathrm{Mn}$ based catalysts," Chem. Communication, Vol. 5, 2012, pp. 452-453.

[48] W. T. Mu, J. Zhu, S. Zhang, Y. Y. Guo, L. Q. $\mathrm{Su}, \mathrm{X} . \mathrm{Y} . \mathrm{Li}$ and $\mathrm{Z}$. Li, "Styrene hydrogenation performance of $\mathrm{Pt}$ nanoparticles with controlled size prepared by atomic layer deposition," Catal. Sci.Technol, Vol. 6,2016, pp. 7532-7548.

[49] C. U. I. Odenbrand, "Urea-SCR Technology for deNOx After Treatment of DieseL Exhausts," Chem. Eng. Res. Des, Vol. 86, 2008, pp. 663-672.

[50] J. P. Chen, M. A. Buzanowski, R. T. Yang and J. E. Cichanowicz, "Deactivation of the Vanadia Catalyst in the Selective Catalytic Reduction," Process Air Waste Manage, Vol. 40, 1990, pp. 1403-1409.

[51] X. Y. Guo, [MS Dissertation], Brigham Young University, 2006, pp. 25-28.

[52] L. Chmielarz, R. Dziembaj, T. Łojewski, A. Wȩgrzyn, T. Grzybek, J. Klinik and D. Olszewska, "Deactivation of SCR Catalysts by Exposure to Aerosol Particles of Potassium and Zinc Salts," Solid State Ionics, Vol. 141, 2001, pp. 715-719.

[53] C. Orsenigo, A. Beretta, P. Forzatti, J. Svachula, E. Tronconi, F. Bregani and A. Baldacci, "Theoretical and experimental study of the interaction between $\mathrm{NO} x$ reduction and $\mathrm{SO}_{2}$ oxidation over DeNO $x$-SCR catalysts," Catal. Today, Vol. 27, 1996, pp. 15-21.

[54] P. D. Ji, X. Gao, X. S. Du, C. H. Zheng, Z. Y. Luo and K. F. Cen, "Relationship between the molecular structure of
$\mathrm{SO}_{2}$ oxidation Catal. Sci.Technol, Vol. 6, 2015, pp. 1187-1194.

[55] G. Busca, L. Lietti, G. Ramis and F. Berti, "Characterization and Reactivity of V2O5MoO3/TiO2 De-NOx SCR Catalysts" Appl. Catal. B, Vol. 18, 1998, pp. 1-36.

[56] K. Wijayanti, K. Leistner, S. Chand, A. Kumar, K. Kamasamudram, N. W. Currier, A. Yezerets and L. Olsson, "Deactivation of $\mathrm{Cu}-\mathrm{SSZ}-13$ by $\mathrm{SO}_{2}$ exposure under SCR conditions," Catalysis Science \& Technology, Vol. 6, 2016, pp. 2565-2579.

[57] A. Kumar, J. Li, J. Luo, S. Joshi, A. Yezerets and K. Kamasamudram, "Catalyst Sulfur Poisoning and Recovery Behaviours: Key for Designing Advanced Emission Control Systems," SAE International, 2017.

[58] Y. Cheng, C. Lamberg, D. H. Kim, J. H. Kwak, S. J. Cho and C. H. Peden, "The different impacts of $\mathrm{SO} 2$ and $\mathrm{SO} 3$ on Cu/zeolite SCR catalysts," Catalysis Today, Vol. 151, 2010, pp. 266-270.

[59] C. Wang, J. Wang, J. Wang, T. Yu, M. Shen, W. Wang and W. Li, "The effect of sulfate species on the activity of NH3-SCR over Cu/SAPO-34," Applied Catalysis B: Environmental, Vol. 204, 2017, pp. 239-249.

[60] Y. Cheng, C. Montreuil, G. Cavataio and C. Lambert, "The Effects of $\mathrm{SO} 2$ and $\mathrm{SO} 3$ Poisoning on $\mathrm{Cu} /$ Zeolite SCR Catalysts," SAE International, Dearborn, USA, 2009.

[61] A. Kumar, M. A. Smith, K. Kamasamudram, N. W. Currier, H. An and A. Yezerets, "Impact of different forms of feed sulfur on small-pore Cu-zeolite SCR catalyst," Catalysis Today, Vol. 231, 2014, pp. 75-82.

[62] W. Tang, X. Huang and S. Kumar, "Department of Energy," 04 October 2011. [Online].Available:https://energy.gov/sites/pr od/files/2014/03/f8/deer11_tang.pdf.[Accesse d April 3 2017].

[63] Y. Jangjou, D. Wang, Kumar, Ashok, J. Li and W. S. Epling, "SO2 Poisoning of the NH3-SCR Reaction over Cu-SAPO-34: Effect of Ammonium Sulfate versus Other SContaining Species," ASC Catalysis, Vol. 6, 2016, pp. 6612-6622.

[64] M. Shen, H. Wen, T. Hao, T. Yu, D. Fan, J. Wang, W. Li and J. Wang, "Deactivation mechanism of $\mathrm{SO}_{2}$ on $\mathrm{Cu} / \mathrm{SAPO}-34 \mathrm{NH} 3-$ SCR catalysts: structure and active $\mathrm{Cu} 2+$, Catalysis Science \& Technology, Vol. 5, 2015, pp. 1741-1749.

[65] Y. Jangjou, D. Wang, A. Kumar, J. Li and W. S. Epling, "SO3 Posioning of the NH3-SCR Reaction over Cu-SAPO-34," ACS Catalysis, Vol. 6, 2016, pp. 6716-6728.

[66] J. Luo, D. Wang, A. Kumar, J. Li, K. Kamasamudram, N. Currier and A. Yezerets, 
"Identification of two types of $\mathrm{Cu}$ sites in [69] $\mathrm{Cu} / \mathrm{SSZ}-13$ and their unique responses to hydrothermal aging and sulfur poisoning," Catalysis Today, Vol. 267, 2016, pp. 3-9.

[67] Y. Jangjou, D. Wang, A. Kumar, J. Li, and S. William, " $\mathrm{SO}_{2}$ Poisoning of the $\mathrm{NH}_{3}-\mathrm{SCR}$ Reaction over Cu-SAPO-34: Effect of Ammonium Sulfate versus Other $\mathrm{S}$ containing Species," ACS Catal, 6, 2016, pp. 6612-6622.

[68] S. Dahlina, C. Lanttob, J. Englund, B. Westerbergd, F. Regalid, M. Skoglundhc, L. J. Petterssona, "Chemical aging of $\mathrm{Cu}$-SSZ13 SCR catalysts for heavy-duty vehicles Influence of sulfur dioxide," Catalysis Today 320, 2019, pp. 72-83.
Y. Shan, X. Shi, Z. Yan, J. Liu, Y. Yu, H. $\mathrm{He}$, "Deactivation of Cu-SSZ-13 in the presence of SO2 during hydrothermal aging," Catalysis Today, 320, 2019, pp. 84-90.

[70] M. Shen, Y. Zhang, J. Wang, C. Wang, J. Wang, "Nature of SO3 poisoning on $\mathrm{Cu} / \mathrm{SAPO}-34$ SCR catalysts," Journal of Catalysis, 358, 2018, pp. 277-286.

[71] P. S. Hammershoi, P. N.R. Vennestrom, H. Falsig, A. D. Jensen, T. V.W. Janssens, "Importance of the $\mathrm{Cu}$ oxidation state for the $\mathrm{SO} 2-$ poisoning of a $\mathrm{Cu}-\mathrm{SAPO}-34$ catalyst in the $\mathrm{NH}_{3}-\mathrm{SCR}$ reaction," Applied Catalysis $\mathrm{B}$ : Environmental. 236, 2018, pp. 377-383. 